\title{
POLYPHENOL AND TRITERPENOID CONSTITUENTS OF Eugenia florida DC. (MYRTACEAE) LEAVES AND THEIR ANTIOXIDANT AND CYTOTOXIC POTENTIAL
}

\author{
Priscila F. P. Santos ${ }^{\mathrm{a}, \mathrm{b}}$, Luiz N. L. F. Gomes ${ }^{\mathrm{b}}$, José L. Mazzeic, Ana Paula A. Fontão ${ }^{\mathrm{c}}$, André L. F. Sampaio ${ }^{\mathrm{c}}$, Antonio C. \\ Siani ${ }^{\mathrm{c}, \#}$ and Ligia M. M. Valente ${ }^{\mathrm{b}, *}$ \\ ${ }^{a}$ Centro Federal de Educação Tecnológica Celso Suckow da Fonseca, Campus Angra dos Reis, 23953-030 Angra dos Reis - RJ, Brasil \\ 'Instituto de Química, Centro de Tecnologia, Universidade Federal do Rio de Janeiro, 21941-909 Rio de Janeiro - RJ, Brasil \\ 'Fundação Oswaldo Cruz, Instituto de Tecnologia em Fármacos, Rua Sizenando Nabuco 100, Manguinhos, 21041-250 Rio de \\ Janeiro - RJ, Brasil
}

Recebido em 05/06/2018; aceito em 13/08/2018; publicado na web em 11/09/2018

\begin{abstract}
Leaves of Eugenia florida DC. have been used in folk medicine as hypotensive, hypoglycemic, antipyretic and for gastrointestinal disorders, among others. In this study dried leaves were extracted with ethanol and the extract was partitioned with hexane, $\mathrm{CHCl}_{3}$, EtOAc, $\mathrm{BuOH}$ and water to afford triterpenoid- and polyphenol-rich fractions which were analyzed by GC-MS and UFLC-DADESI-Ion Trap-MS ${ }^{n}$. All fractions were tested against the proliferation of leukemic K562 and human melanoma SK-Mel-28 cell lines and for their ability to scavenge DPPH radical. Twenty-nine compounds were fully identified (among triterpenic and phenolic acids, flavonol- and dihydroflavonol-monoglyclosides) based on mass fragmentation patterns and comparison to standards and/or literature data. The ability to scavenge DPPH radical resulted in the following order: $\mathrm{BuOH} \approx \mathrm{EtOAc}>$ crude extract $\approx$ Water $>\mathrm{CHCl}_{3}>$ hexane; with the two most active reaching half of the TBHQ control potency $\left(\mathrm{EC}_{50} 6.59 \pm 0.03 \mu \mathrm{g} \mathrm{mL}-1\right)$. On testing against the proliferation of K562 and SK-Mel-28 cell lines, the most significant inhibitions were achieved on the former by the crude extract $\left(\mathrm{IC}_{50} 12 \mu \mathrm{g} \mathrm{mL} \mathrm{L}^{-1}\right)$ and the hexane and EtOAc fractions at $15 \mu \mathrm{g} \mathrm{mL}{ }^{-1}$.
\end{abstract}

Keywords: Eugenia florida; polyphenols; triterpenoids; antioxidant activity; cytotoxic activity.

\section{INTRODUCTION}

The Myrtaceae Juss. family comprises nearly 6000 species in approximately 140 genera $^{1}$ worldly distributed in tropical and subtropical regions, with diversity centers in Australia, Southeast Asia and South America and few species occurring in Africa. The genus Eugenia L. is one of the largest of the family, with ca. 1000 species distributed from Mexico to Argentina. Leaves, fruits and seeds of Eugenia species, in addition to essential oils, contain steroids, triterpenoids, flavonoids and hydrolysable tannins. ${ }^{2,3}$

The species Eugenia florida DC. (EF) is a small black-fruited tree, popularly known as pitanga-preta or guamirim, which thrives in all the Brazilian territory. Leaves of this species have been used in folk medicine as hypotensive, hypoglycemic, antipyretic and for gastrointestinal disorders, among others. ${ }^{3}$ The ethanol leaf extract showed antimicrobial activity ${ }^{3}$ and insecticide activity was demonstrated for methanol extracts from several parts of the plant. ${ }^{4}$ Chemical studies on the leaves composition revealed the presence of mono- and sesquiterpenes in the essential oil, ${ }^{5}$ triterpene acids and some of their glucosides, ${ }^{2,6,7}$ and polyphenolics. ${ }^{3}$

This article describes a comprehensive chemical study of the ethanol leaf extract of E. florida, its antioxidant and cytotoxic activities. The crude ethanol extract was partitioned with solvents of different polarity. The initial phytochemical screening of the fractions derived thereafter were complemented with chromatographic separations and mass spectrometry studies. All the samples were tested by the antioxidant and cytotoxic activities by means of their ability to scavenge DPPH radical and inhibit the in vitro growth of myeloblast K562 (chronic myeloid leukemia) and SK-Mel-28 (human melanoma) cell lines. The chemical

*e-mail: valente@iq.ufrj.br

\#e-mail alternativo: antonio.siani@far.fiocruz.br profiles were putatively correlated with the results of the observed bioactivities.

\section{EXPERIMENTAL}

\section{Chemicals and reagents}

Chloroform, hexane, ethanol, ethyl acetate, methanol and acetonitrile were purchased from Tedia (Brazil). Ferric chloride, formic acid $85 \%$, glacial acetic acid, sodium carbonate, dimethyl sulfoxide and sulfuric acid from Vetec (Brazil). 2 N Folin-Ciocalteu's phenol reagent and tannic acid from Fluka BioChemika (Germany). Quercetin, myricetrin, betulinic acid, oleanolic acid, ursolic acid, 2-aminoethyldiphenylborinate (NP), Polyethylene glycol 400 (PEG), 3-(4,5-dimethylthiazol-2-yl)-2,5-diphenyl tetrazolium bromide (MTT), staurosporine, $N$-methyl- $N$-trimethylsilyltrifluoroacetamide (NSTFA) with 2\% TMSCl and 2,2-diphenyl-1-picrylhydrazyl radical from Sigma Aldrich (USA). Tert-butylhydroquinone (TBHQ) from Plury Quimica (Brazil). Aluminium chloride from Riedel-de Haën (Germany).

\section{Plant material}

Leaves of Eugenia florida (500 g) were collected in a private area in Campinas, State of São Paulo (S 22 57' 31.4”/ W 46 57' 21.1'”), Brazil in May 2013. A voucher specimen is deposited in the Herbarium of Rio de Janeiro Federal University under registration $n^{\circ}$ RFA 39907. Legal access of the genetic heritage component was authorized by CGEN/CNPq under protocol number 010579/2013-3.

\section{Extraction and fractionation of the crude extracts}

Air-dried leaves of E. florida (210 g) were macerated with $2 \mathrm{~L}$ 
of ethanol at room temperature to yield, after removing the solvent in a rotary evaporator $\left(40{ }^{\circ} \mathrm{C}\right), 24.2 \mathrm{~g}$ of crude extract. Part of this $(1.7 \mathrm{~g})$ was re-suspended in $8: 2$ methanol-water $(200 \mathrm{~mL}, \mathrm{v} / \mathrm{v})$ and partitioned with hexane $(100 \mathrm{ml} \times 6)$, to afford the hexane-soluble extract (244.7 mg). Aqueous-MeOH layer was added of more $100 \mathrm{~mL}$ of water and partitioned with chloroform $(100 \mathrm{~mL} \times 6)$ to afford a $\mathrm{CHCl}_{3}$-soluble extract $(437.5 \mathrm{mg})$. The organic solvent of aqueous $\mathrm{MeOH}$ layer was evaporated and the aqueous residue was submitted to liquid-liquid partition with ethyl acetate $(100 \mathrm{~mL} \times 6)$, to afford the EtOAc-soluble extract (247.8 mg). Finally, the aqueous layer was partitioned with saturated butanol $(100 \mathrm{~mL} \times 2 ; 218.7 \mathrm{mg})$ and the aqueous residue was freeze-drying, yielding $229.0 \mathrm{mg}$.

\section{TLC analysis}

The fractions obtained from liquid-liquid partition were solubilized in methanol at $10 \mathrm{mg} \mathrm{mL}^{-1}$. Aliquots $(10 \mu \mathrm{L})$ were applied ( $0.5 \mathrm{~cm}$ bands with $0.5 \mathrm{~cm}$ spacing between the spots) on silica gel $60 \mathrm{~F}_{254}$ pre-coated plates (Merck, Germany) with the aid of Hamilton syringe. Phytochemical prospection was carried out by eluting the plates up to $7.0 \mathrm{~cm}$ high with three different solvent systems. The spots were visualized under UV-irradiation at 254 and $365 \mathrm{~nm}$, and then sprayed with specific chromogenic agents (Table 1), according to the target chemical class. Standard solutions in methanol $(5 \mu \mathrm{L}$, $1 \mathrm{mg} \mathrm{mL}^{-1}$ ) were used as positive control.

\section{Total phenolic content determination}

The total phenolic content was determined by the Folin-Ciocalteu method as previously described. ${ }^{8}$ In 96-well microplates, aliquots of the methanolic sample solution $(20 \mu \mathrm{L})$ of each fraction or standard solution or solvent (blank) was added and mixed with $0.2 \mathrm{~N}$ FolinCiocalteu solution $(100 \mu \mathrm{L})$. After $5 \mathrm{~min}$ of incubation, $\mathrm{Na}_{2} \mathrm{CO}_{3}$ $(80 \mu \mathrm{L}, 7.5 \%$, w/v) was added, allowed to stand for $2 \mathrm{~h}$ in dark ambient and then the absorbance at $760 \mathrm{~nm}$ was measured in a SpectraMax Plus 384 microplate reader (Molecular Devices). The difference between the absorbances of each fraction or standard solutions and its respective blank absorbance was determined. A standard curve of quercetin was prepared with five-points (triplicate) ranged between $3.125-75.00 \mu \mathrm{g} \mathrm{mL}^{-1}(\mathrm{r}=0.998)$. The concentration of total phenolic compounds of methanolic solutions was performed by comparing with the quercetin standard curve and the results were expressed as microgram of quercetin equivalents $(\mathrm{QE}) \mathrm{mg} \mathrm{g}^{-1}$ of dried fraction.

\section{Total flavonoid content determination}

The measurement of flavonol and flavone total content was performed as previously reported. ${ }^{8}$ Briefly, $20 \mu \mathrm{L}$ of methanolic solution of each sample, $20 \mu \mathrm{L}$ of $1 \mathrm{~mol} \mathrm{~L}^{-1}$ sodium acetate ( $\mathrm{pH} 8$ ) and $180 \mu \mathrm{L}$ of distillated water were previously mixed in 96-well microplate, followed by the addition of $20 \mu \mathrm{L}$ of $6 \%$ aluminum chloride in methanol. After $30 \mathrm{~min}$ of incubation at room temperature, the absorbance was measured at $430 \mathrm{~nm}$ in a SpectraMax ${ }^{\circledR}$ M2e microplate reader (Molecular Devices) against the blank sample. A standard curve of quercetin was built with five-points (triplicated injections) ranging from 3.125 to $50.00 \mu \mathrm{g} \mathrm{mL} \mathrm{m}^{-1}(\mathrm{r}=0.998)$.

\section{DPPH antioxidant assay}

The measurement of the DPPH radical scavenging activity was performed according to the methodology described by Fernandes $e t$ $a l .{ }^{9}$ In each 96-well microplate, the first line was used as $100 \%$ DPPH control mixing equals volume $(100 \mu \mathrm{L})$ of methanol $(\mathrm{MeOH})$ and $0.1 \mathrm{mmol} \mathrm{L}^{-1} \mathrm{DPPH}$ in three wells. The blank of control was prepared with $200 \mu \mathrm{L} \mathrm{MeOH}$. The analytical curve of each sample was prepared with five concentrations levels (triplicate). For each concentration level of sample solution was used one line with six wells with $100 \mu \mathrm{l}$ of each solution. In three wells was added $100 \mu \mathrm{L}$ of DPPH and in the other three wells was added $100 \mu \mathrm{L}$ of $\mathrm{MeOH}$, as sample blank. After 30 min of incubation in the dark at room temperature, the absorbance at $517 \mathrm{~nm}$ was measured in a SpectraMax ${ }^{\circledR}$ M2e microplate reader. SoftMax Pro 6 software was used for data acquisition. A standard curve of TBHQ was prepared with the same procedure. The percentage of radical scavenging was obtained using the following expression: \% DPPH scavenging $=100 \times[($ Abs Sample + DPPH $)-($ Abs Sample Blank)] / [(Abs DPPH) - (Abs Solvent)]. The efficient concentration $\left(\mathrm{EC}_{50}\right)$ was calculated by the interpolation in the first-order \% DPPH scavenging versus concentration levels of the curve for each sample.

\section{GC-MS analysis}

The analyses were performed on an Agilent 5975C GC/MSD (Agilent Technologies, U.S.A.) with 5\% phenyl - $95 \%$ dimethylpolysiloxane HP-5 MS column $30 \mathrm{~m} \times 0.25 \mathrm{~mm}(0.30 \mu \mathrm{m}$ film thickness). A linear gradient from $100{ }^{\circ} \mathrm{C}$ to $300{ }^{\circ} \mathrm{C}$ at a rate of $20{ }^{\circ} \mathrm{C} \mathrm{min}{ }^{-1}$ followed by an isotherm for $15 \mathrm{~min}$ was employed. Helium (He) was used as a carrier gas at a flow rate of $1 \mathrm{~mL} \mathrm{~min}{ }^{-1}$. The electron ionization detector was operated at $70 \mathrm{eV}$, with the mass scanned in the range $\mathrm{m} / \mathrm{z} 30-800$. The temperature of the MSD transfer line was $280{ }^{\circ} \mathrm{C}$. The temperature of the ion source was $230{ }^{\circ} \mathrm{C}$, and that of the MS quadrupole was $150{ }^{\circ} \mathrm{C}$. Data were adquired and processed by HP ChemStation version 02.02.1431 (Agilent Technologies, U.S.A.). The samples were derivatizated with $100 \mu \mathrm{L}$ of NSTFA at $80^{\circ} \mathrm{C}$ for 30 min before analysis and $1 \mu \mathrm{L}$ was injected with split ratio 1:10. The standard compounds (oleanolic acid, betulinic acid, ursolic acid and lupeol) were also analyzed as

Table 1. TLC conditions used for the phytochemical prospection of the ethanol leaf extract of Eugenia florida and their derived fractions

\begin{tabular}{|c|c|c|c|}
\hline Chemical class & Mobile Phase & Specific chromogenic agent & $\begin{array}{c}\text { Standard color } \\
\text { (standard substance) }\end{array}$ \\
\hline Pentacyclic triterpenic acid & $\begin{array}{c}\mathrm{BuOH} / \mathrm{CH}_{3} \mathrm{COOH} / \mathrm{H}_{2} \mathrm{O}(4: 1: 1, \mathrm{v} / \mathrm{v} / \mathrm{v}) \\
\mathrm{CHCl}_{3} / \mathrm{MeOH}(15: 1, \mathrm{v} / \mathrm{v})\end{array}$ & $\begin{array}{l}\text { Anisaldehyde } / \mathrm{H}_{2} \mathrm{SO}_{4} \text { and heating } \\
\text { at } 100{ }^{\circ} \mathrm{C}(5 \mathrm{~min})\end{array}$ & $\begin{array}{l}\text { violaceous (betulinic, oleanolic } \\
\text { and ursolic acid) }\end{array}$ \\
\hline Hydrolysable and Condensed tannin & $\begin{array}{c}\text { EtOAc/ } \mathrm{HCOOH} / \mathrm{CH}_{3} \mathrm{COOH} / \mathrm{H}_{2} \mathrm{O} \\
(100: 11: 11: 27, \mathrm{v} / \mathrm{v} / \mathrm{v} / \mathrm{v})\end{array}$ & $\mathrm{FeCl}_{3} 1 \%$ in $\mathrm{MeOH}$ & $\begin{array}{l}\text { blue (tannic acid) and green } \\
\text { (non-specific phenols) }\end{array}$ \\
\hline Condensed Tannin & $\begin{array}{c}\text { EtOAc/HCOOH } / \mathrm{CH}_{3} \mathrm{COOH} / \mathrm{H}_{2} \mathrm{O} \\
(100: 11: 11: 27, \mathrm{v} / \mathrm{v} / \mathrm{v} / \mathrm{v})\end{array}$ & $\begin{array}{l}\text { Vanillin } / \mathrm{H}_{2} \mathrm{SO}_{4} \text { and heating } \\
\text { at } 100{ }^{\circ} \mathrm{C}(5 \mathrm{~min})\end{array}$ & orange (catechin and epicatechin) \\
\hline Ellagitannin & $\begin{array}{c}\mathrm{EtOAc} / \mathrm{HCOOH} / \mathrm{CH}_{3} \mathrm{COOH} / \mathrm{H}_{2} \mathrm{O} \\
(100: 11: 11: 27, \mathrm{v} / \mathrm{v} / \mathrm{v} / \mathrm{v})\end{array}$ & $\begin{array}{c}\mathrm{NaNO}_{2} / \mathrm{CH}_{3} \mathrm{COOH} \text { and heating } \\
\text { at } 100{ }^{\circ} \mathrm{C}(5 \mathrm{~min})\end{array}$ & brownish orange (geraniin) \\
\hline Flavonoid and phenolic acid & $\begin{array}{c}\text { EtOAc/HCOOH} / \mathrm{CH}_{3} \mathrm{COOH} / \mathrm{H}_{2} \mathrm{O} \\
(100: 11: 11: 27, \mathrm{v} / \mathrm{v} / \mathrm{v} / \mathrm{v})\end{array}$ & $\begin{array}{l}\text { NP/PEG followed by observation } \\
\text { at UV } 365 \mathrm{~nm}\end{array}$ & $\begin{array}{l}\text { yellow, green and orange (flavonoids); } \\
\text { blue and green (phenolic acids) }\end{array}$ \\
\hline
\end{tabular}


trimethylsilyl derivatives. Automatic Mass Spectral Deconvolution and Identification System (AMDIS) software was used to analyze the total ion chromatograms (TIC) and identify the target compounds followed by the analysis of the extracted ion chromatograms (EIC).

\section{UFLC-DAD-IT-MS/MS analysis}

A Prominence UltraFast liquid chromatograph UFLC (Shimadzu Corporation, Kyoto, Japan) equipped with a quaternary pump, vacuum degasser, autosampler, oven and the photodiode-array detector was used for $\mathrm{MS}^{\mathrm{n}}$ analyses. The phenolic compounds were analyzed on a 150 x $2.0 \mathrm{~mm}$ i.d., $2.2 \mu \mathrm{m}$ particle size, C18 Shimpack XR-ODSIII column (Shimadzu Corporation, Kyoto, Japan). The mobile phase was constituted by ultrapure water $0.1 \% \mathrm{HCOOH}$, $\mathrm{pH} 3$ (phase A) and acetonitrile (phase B) in linear gradient mode steps: $0-8.7 \mathrm{~min}$, from $10 \%$ to $20 \% \mathrm{~B} ; 10.0 \mathrm{~min}$, to $30 \% \mathrm{~B} ; 15 \mathrm{~min}$, to $50 \% \mathrm{~B} ; 17.5 \mathrm{~min}$, to $95 \% \mathrm{~B} ; 20 \mathrm{~min}$, to $100 \% \mathrm{~B}$ held for $2.5 \mathrm{~min}$ at a flow rate of $0.3 \mathrm{~mL} \mathrm{~min}^{-1}$. The chromatograms were acquired at $190-800 \mathrm{~nm}$ with slope $20 \mathrm{mAU} \mathrm{s}^{-1}$. Nitrogen was used as desolvation gas, at $180{ }^{\circ} \mathrm{C}$ and a flow rate of $300 \mathrm{~L} \mathrm{~h}^{-1}$. Mass spectra, $\mathrm{m} / z$ range 100-1000, were acquired using an amaZon SL ${ }^{\mathrm{TM}}$ IonTrap quadrupole (Bruker Daltonics, USA) equipped with an electrospray ionization source in the positive and negative ionization mode. Helium was used as collision gas in the $\mathrm{MS}^{\mathrm{n}}$ experiments and two different fragmentation energies in each mode (negative mode: 0.13 and $0.20 \mathrm{~V}$ and positive mode: 0.10 and $0.30 \mathrm{~V}$ ). The data were gathered using HyStar ${ }^{\circledR}$ Workstation software and processed in the Bruker Compass DataAnalysis 4.4.

\section{Cytotoxicity assays}

The fractions of the partition were subjected to analyses of cytotoxicity for two lineages of different tumor cells: human myeloid leukemia K562 and human melanoma SK-Mel-28 by the method spectrophotometric MTT. Firstly, samples were solubilized in DMSO and stored at $-20{ }^{\circ} \mathrm{C}$. To SK-Mel-28 cells culture, samples were solubilized in Dulbecco's modified Eagle medium (DMEM) and K562 cells culture with Roswell Park Memorial Institute medium (RPMI 1640). Both media were supplemented with $10 \%$ fetal bovine serum, $100 \mathrm{UI}^{-1}$ penicillin, $0.1 \mathrm{mg} \mathrm{mL}^{-1}$ streptomycin and $0.05 \mathrm{mg} \mathrm{mL}^{-1}$ gentamicin before the experiments. Cell suspensions were prepared at a concentration of $5 \times 10^{4} \mathrm{cells} \mathrm{mL}^{-1}$, and aliquots of each of the suspensions $(100 \mu \mathrm{L})$ were incubated in a 96-multi-well plate for $24 \mathrm{~h}\left(37^{\circ} \mathrm{C}\right.$ and $\left.5 \% \mathrm{CO}_{2}\right)$. After this period an aliquot of fraction DMSO solution to the culture medium was added finalizing at $15 \mu \mathrm{g} \mathrm{mL}^{-1}$ and cultures were incubated for $48 \mathrm{~h}$. Then, thiazolyl blue was added and the plate was incubated at $37{ }^{\circ} \mathrm{C}$ for $4 \mathrm{~h}$. After discarding the supernatant, formazan crystals were dissolved in DMSO and optical density measured on a VictorX5 multiwell spectrophotometer at $540 \mathrm{~nm}$ (Perkin, USA). For control experiments, cells were treated with medium containing equivalent concentrations of DMSO. Paclitaxel $0.2 \mu \mathrm{M}$ and Staurosporine $5 \mu \mathrm{mol} \mathrm{L}-1$ were used as positive controls and showed inhibition of K562 cell proliferation of $70.6 \pm 1.5$ and $52.0 \pm 1.3 \%$, respectively.

\section{Statistical analysis}

All analyses were performed in triplicates and the results were expressed in mean and standard deviation values. Grubb's test was used to detect the outliers' values between replicates. Groups were compared using a one-way ANOVA analysis for identification of significant statistical differences followed by Tukey's Multiple Comparison Test using Graph Pad Prism version 5.01.

\section{RESULTS AND DISCUSSION}

The crude ethanolic extract of Eugenia florida leaves was sequentially partitioned with hexane, chloroform, ethyl acetate, butanol and water. The resulting fractions were preliminary prospected by TLC for triterpenes, phenolic acids, flavonoids, hydrolysable tannins, condensed tannins and ellagitannins, given that these classes of compounds have usually been described in Myrtaceae species. The results revealed triterpenes in the two less polar fractions and phenolic compounds in all but hexane. Tannins were not detected (Table 1S).

The chemical profiles of the hexane and chloroform fractions were accessed by GC-MS after trimethylsilylation with NSTFA. This strategy has been proven advantageous in the chromatographic separation of isomeric compounds ${ }^{10}$ and in the identification of those containing hydroxyl and carboxyl groups, thus easily discriminating these from the naturally methoxylated and/or acetylated compounds. The fragmentation patterns of the silylated derivatives correlate quite well with the non-silylated compounds. ${ }^{11-14}$ In spite of these advantages, the available databases and MS softwares on metabolomics still are not embedded with enough representative sampling of silylated compounds' fragmentation. The mass fragmentation pattern of each MS signal was compared with data from the literature and metabolomics databases such as The Human Metabolome Database (HDMB), Mass Bank - High Quality Mass Spectral Database and NIST Standard Reference Data. ${ }^{15}$

The MS of silylated compounds show diagnostic ions such as $m / z, 73$ produced by ionized trimethylsilane (TMS) $\left[\left(\mathrm{CH}_{3}\right)_{3} \mathrm{Si}\right]^{+}$as well as those related to the loss of methyl group ( $15 \mathrm{Da}) . O$-silylated derivatives will show loss of neutral fragments at $90 \mathrm{Da}$ (TMSOH) (e.g.) and $118 \mathrm{Da}$ (HCOOTMS) (Table 2).

Pentacyclic triterpenoid compounds are largely present in Eugenia species, particularly those with lupane, ursane and oleanane skeletons. ${ }^{2,16}$ The fragments originated from retro-Diels-Alder (rDA) reaction in the $\mathrm{C}$ ring and their relative abundances are important tools to identify and differentiate between $\Delta^{12}$-oleanene- and $\Delta^{12}$-ursene-type triterpenoids. ${ }^{11}$ This cleavage mode involves rupture of the $C(8)-C(14)$ and $C(9)-C(11)$ bonds to result in fragments containing the $\mathrm{ABC}^{*}$-rings and the $\mathrm{C} * \mathrm{DE}$-rings $(*$ indicates the ring undergoing fragmentation, according to the nomenclature proposed by Burnouf-Radosevich et al. $)^{17}$ (Figure 1). The $\mathrm{C}^{*} \mathrm{DE}$ fragment has been employed as diagnostic for the presence of a 12(13) double bond in pentacyclic triterpenes. ${ }^{11}$ On the same hand, the two $\Delta^{12}$-silylated oleanolic and ursolic acids may be easily identified by the resulting ion at $m / z 320$ (Figure 1). Consequently, the $\mathrm{ABC}^{*}$ mass fragment is determined by the difference between the mass of the molecular ion and that originated from the $\mathrm{C} * \mathrm{DE}$ fragment ion. The $\mathrm{C} * \mathrm{DE}$ fragment is subject to further fragmentation yielding the ion at $\mathrm{m} / \mathrm{z}, 203$ as the base peak (Figure 1, Table 2), reflecting the favored rDA cleavage that produces a conjugate diene system. The fragment at $\mathrm{m} / \mathrm{z}, 279$ is related to the $\mathrm{ABC} *$ moiety, by losing the neutral $\left(\mathrm{CH}_{3}\right)_{3} \mathrm{SiOH}$ group to afford the ion at $m / z, 189^{18}$ (Figure 1).

Lupeol and betulinic acid are triterpenoids presenting saturated pentacyclic skeleton with an isopropenyl side chain in the E ring, where an important mass fragment arises from the cleavage $\mathrm{C}(8)-\mathrm{C}(14)$ to yield the corresponding $\mathrm{C} * \mathrm{DE}$ and $\mathrm{ABC}^{*}$ fragments (Figure 2). A similar further fragmentation of the $\mathrm{C} * \mathrm{DE}$ fragment ion is also observed with differences in the relative abundance depending on the $C(17)$ substituent. When this carbon bears a methyl group, e.g. lupeol, the ion at $m / z, 189$ arises as base peak. Yet, the presence of a functionalized substituent results in a slight decreasing of its relative abundance. ${ }^{19}$

The relation between the relative abundances of the fragment ions at $\mathrm{m} / z, 203$ and 189 and their respective C*DE fragment is an 
Table 2. Triterpenoids identified by GC-MS in the hexane and chloroform fractions from the ethanol leaf extract of Eugenia florida and their diagnostic fragments ${ }^{\mathrm{a}}$

\begin{tabular}{|c|c|c|c|c|c|c|c|c|c|c|c|}
\hline \multirow{2}{*}{ Peak } & \multirow{2}{*}{$\begin{array}{c}R \mathrm{t} \\
(\mathrm{min})\end{array}$} & \multirow{2}{*}{ Compound } & \multirow{2}{*}[\mathrm{M}]{$^{+}$} & \multicolumn{3}{|c|}{$\left[\mathrm{M}-\mathrm{R}^{1} \text { or } \mathrm{R}^{2}\right]^{+}$} & \multirow{2}{*}[\mathrm{C}^{*}\mathrm{DE}\text{rings}]{$^{+}$} & \multirow{2}{*}[C^{*}\text{DErings}-\mathrm{R}^{2}]{$^{+}$} & \multirow{2}{*}[\mathrm{ABC}^{*}\text{rings}]{$^{+}$} & \multirow{2}{*}[\mathrm{ABC}*\text{rings}-\mathrm{R}^{1}]{$^{+}$} & \multirow{2}{*}{$\mathrm{TMS}^{+}$} \\
\hline & & & & $\mathrm{CH}_{3}$ & HOTMS & HOOCTMS & & & & & \\
\hline 2 & 18.4 & Lupeol & $498(22)$ & $483(6)$ & $408(4)$ & n.d. & $218(30)$ & $203(7)$ & $279(10)$ & $189(5.6)$ & $73(100)$ \\
\hline 3 & 19.2 & $\begin{array}{l}\text { Lupane-type } \\
\text { triterpenoid }\end{array}$ & $560(6.7)$ & $545(10)$ & $470(9)$ & - & $266(18)$ & - & $293(1.9)$ & - & $73(100)$ \\
\hline 4 & 20.1 & Erythrodiol & nd & $571(<1)$ & $496(37)$ & nd & nd & $\begin{array}{l}216(51) \\
203(50)\end{array}$ & 279 (3.6) & $189(29)$ & $73(100)$ \\
\hline 5 & 20.7 & $\begin{array}{l}\text { Ursane-type } \\
\text { triterpenoid }\end{array}$ & $648(<1)$ & $633(3.6)$ & $558(12)$ & $\begin{array}{l}530(3.6) \\
531(11)^{b}\end{array}$ & nd & - & nd & - & $73(100)$ \\
\hline 6 & 20.7 & Uvaol & nd & $571(2)$ & $496(100)$ & nd & $306(<1)$ & $\begin{array}{l}216(55) \\
203(59)\end{array}$ & $279(3.7)$ & $189(27)$ & $73(69)$ \\
\hline 7 & 21.0 & Betulin & $586(3.6)$ & $571(2.2)$ & $496(41)$ & nd & $306(2.9)$ & $\begin{array}{l}216(19) \\
203(63)\end{array}$ & 279 (17) & $189(82)$ & $73(100)$ \\
\hline 8 & 21.2 & $\begin{array}{l}\text { Betulonic } \\
\text { acid }\end{array}$ & $526(17)$ & $511(18)$ & $436(1)$ & $408(20)$ & $320(19)$ & $203(34)$ & 205 (28) & $189(94)$ & $73(100)$ \\
\hline 9 & 21.4 & $\begin{array}{l}\text { Oleanolic } \\
\text { acid }\end{array}$ & nd & $585(6)$ & $510(<1)$ & $482(22)$ & $320(36)$ & $203(100)$ & $279(5.5)$ & $189(36)$ & $73(60)$ \\
\hline 10 & 21.9 & $\begin{array}{l}\text { Betulinic } \\
\text { acid }\end{array}$ & $600(<1)$ & $585(9.5)$ & $510(4.6)$ & $482(9)$ & $320(22)$ & 203 (37) & 279 (15) & $189(87)$ & $73(100)$ \\
\hline 11 & 22.9 & $\begin{array}{l}\text { Betulinic } \\
\text { aldehyde }\end{array}$ & $512(9)$ & 497 (5.7) & $422(7.9)$ & 394 (3.7) & $232(6.9)$ & 203 (27) & 279 (16) & 189 (87) & $73(100)$ \\
\hline 12 & 22.5 & Ursolic acid & nd & $585(8)$ & $510(1.0)$ & 482 (11) & $320(87)$ & $203(100)$ & 279 (10) & $189(35)$ & $73(59)$ \\
\hline 13 & 24.9 & Platanic acid & nd & $587(8)$ & $512(16)$ & $484(4)$ & $320(5)$ & 203 (20) & 279 (10) & $189(95)$ & $73(100)$ \\
\hline 14 & 25.2 & $\begin{array}{l}\text { 1-hydroxy } \\
\text { or } \\
\text { 2-hydroxy- } \\
\text { ursolic acid }\end{array}$ & $688(<1)$ & $673(5.1)$ & 598 (4.9) & $570(18)$ & $320(46)$ & $203(100)$ & 367 (3.5) & $\begin{array}{l}277(12) \\
189(39)^{\mathrm{c}}\end{array}$ & 73 (99) \\
\hline
\end{tabular}

${ }^{\mathrm{a}} \mathrm{m} / \mathrm{z}$ (relative abundance). ${ }^{\mathrm{b}}$ Fragment referring to $[\mathrm{M}-\mathrm{COOTMS}]^{+} .{ }^{\mathrm{c}}$ Fragment referring to $[\mathrm{ABC} * \text { rings }-2(\mathrm{OTMS})]^{+}$. nd $=$not detected.

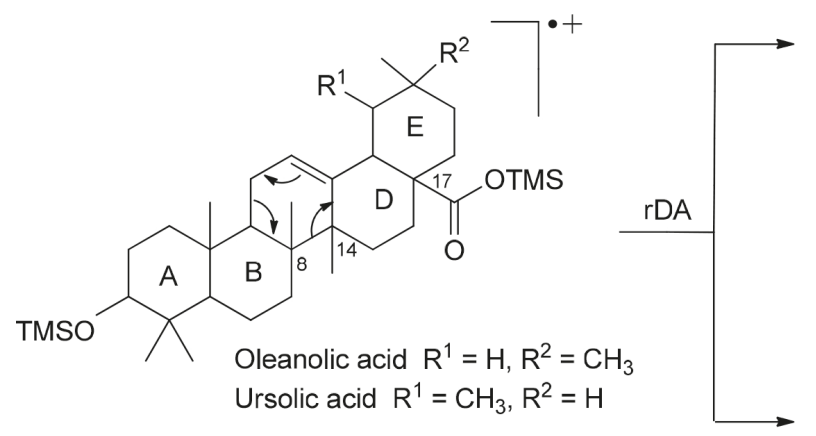

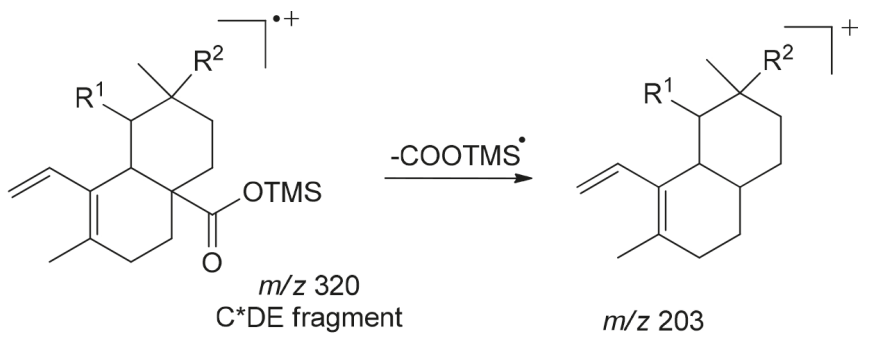

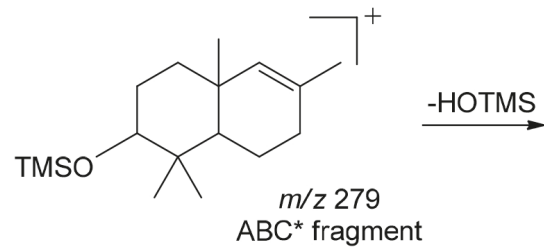

Figure 1. Main fragments arising from retro-Diels Alder cleavages of silylated $\Delta^{12}$-oleanene-and $\Delta^{12}$-ursene-type triterpenic acids by Electron Impact ionization ${ }^{14}$

important tool to determine the pentacyclic triterpenoid type. In general, silylated lupane derivatives with unsaturated side chain are easily recognized by presenting high relative abundance of the ions at $\mathrm{m} / \mathrm{z}, 73$ and 189, as it occurs in lupeol and betulinic acid. A substitution in the $\mathrm{C}-17$ of the lupane derivatives results in a slight decrease in the relative abundance of the ion at $m / z 189 .{ }^{20}$ Oleanolic acid showed a 1:2.5 ratio between base peak and the ion at $\mathrm{m} / \mathrm{z}, 320(\mathrm{C} * \mathrm{DE}$ fragment) while ursolic acid produced a 1:1.2 ratio. The fragment at $m / z, 133$ can also be a valuable tool to differentiate silylated
$\Delta^{12}$-oleanane and $\Delta^{12}$-ursane acids: its relative abundance is $9.4 \%$ in the former and $40 \%$ in the latter. ${ }^{20}$ Analogously, silylated triterpene diols can be distinguished by observing the relative abundance of the $[\mathrm{C} * \mathrm{DE}-\mathrm{HOTMS}]^{+}$fragment, which appears with approximately $85 \%$ in the oleanane-type and $50 \%$ in the ursane-type. ${ }^{21}$ For instace, similar ratio was observed in the MS of the di-hydroxylated isomers maslinic and corosolic acids. ${ }^{12}$

The GC-MS analyses of the hexane and chloroform fractions allowed characterizing saturated and unsaturated fatty acids 


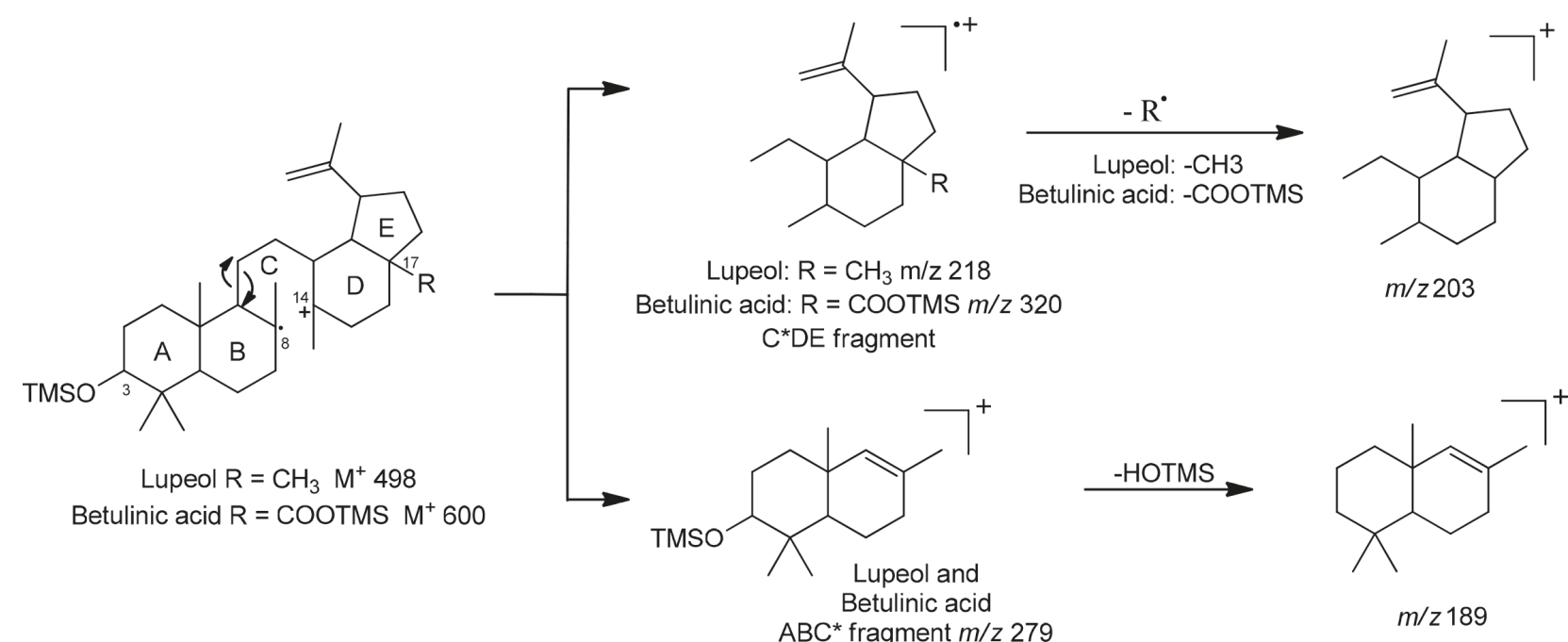

Figure 2. Main fragments of silylated lupane-type triterpenoid derivatives by Electron Impact ionization ${ }^{14}$

and pentacyclic triterpenic acids in both fractions (Figure 3). In addition, sesquiterpenes were identified in the hexane fraction and hydroxycinnamic and phenolic acids, including ferulic, gallic, 2-hydroxybenzoic acid and different sugars were identified in the chloroform fraction (Figure 3, Table 2S). $\beta$-sitosterol (1) (17.55 min) was characterized by comparing its MS with that from the Wiley 275 Database. ${ }^{22}$ The compounds corresponding to the chromatographic peaks 2 (18.43 $\mathrm{min}), \mathbf{9}(21.40 \mathrm{~min}), \mathbf{1 0}$ (21.94 $\mathrm{min})$ and $\mathbf{1 2}(22.47 \mathrm{~min})$ were identified as lupeol, oleanolic acid, betulinic acid and ursolic acid, respectively, by comparing their retention times and MS with those of the silylated authentic standards.

The compound corresponding to peak 3 (19.18 min) showed $\mathrm{M}^{+}$ at $\mathrm{m} / z, 560$ and fragments $\left[\mathrm{M}-\mathrm{CH}_{3}\right]^{+}$and $[\mathrm{M}-\mathrm{OHTMS}]^{+}$at $\mathrm{m} / z, 545$ and 470, respectively. The ions at $\mathrm{m} / z, 293$ and $\mathrm{m} / z, 189$ are indicative of the $\left[\mathrm{ABC}^{*}\right]^{+}$and $\left[\mathrm{ABC}^{*}-\mathrm{CH}_{2} \mathrm{OTMS}\right]$ fragments, respectively, suggesting a $\mathrm{CH}_{2} \mathrm{OH}$ group at $\mathrm{C}(4)$ and a carbonyl group at $\mathrm{C}(3)$ (Figures 1 and 2) of a triterpene moiety. Although inconclusively, compound $\mathbf{3}$ is suggested to be a lupane derivative.
The molecular mass $586 \mathrm{Da}$ assigned for both the compounds corresponding to peaks 4 (20.06 $\mathrm{min})$ and 6 (20.71 $\mathrm{min})$ could be inferred by the fragment at $\mathrm{m} / \mathrm{z} 571$ that results from the loss of a methyl group. They also presented similar fragmentation patterns, highlighting the significant relative abundance of the ion $\left[\mathrm{M}-\mathrm{HOTMS}^{+}\right.$at $\mathrm{m} / \mathrm{z}, 496$, which is the MS base peak for compound 6. The $\mathrm{C}^{*} \mathrm{DE}$ fragment was deduced from the ion at $m / z, 216$ [C*DE - HOTMS ] . This fragment is commonly observed in triterpenoid moieties bearing a $\mathrm{CH}_{2} \mathrm{OTMS}$ group in $\mathrm{C}(17) .{ }^{21}$ The ion at $m / z, 279(189+$ HOTMS $)$ was identified as the ABC* fragment (Figure 1). These data clearly suggest these structures as diol isomers bearing hydroxyl groups in each main rDA fragment (Figure 1). Differentiation between the isomers, as supported by the relative abundances of the fragments at $\mathrm{m} / z, 216$ and 496, led to establish the peak $\mathbf{4}$ as olean-12-ene-3,28-diol (erythrodiol) and peak $\mathbf{6}$ as urs-12-ene-3,28-diol (uvaol). ${ }^{21}$ Additionally, this conclusion is supported by the fact that oleanenes elute before the ursene isomers in GC non-polar stationary phase. ${ }^{23}$
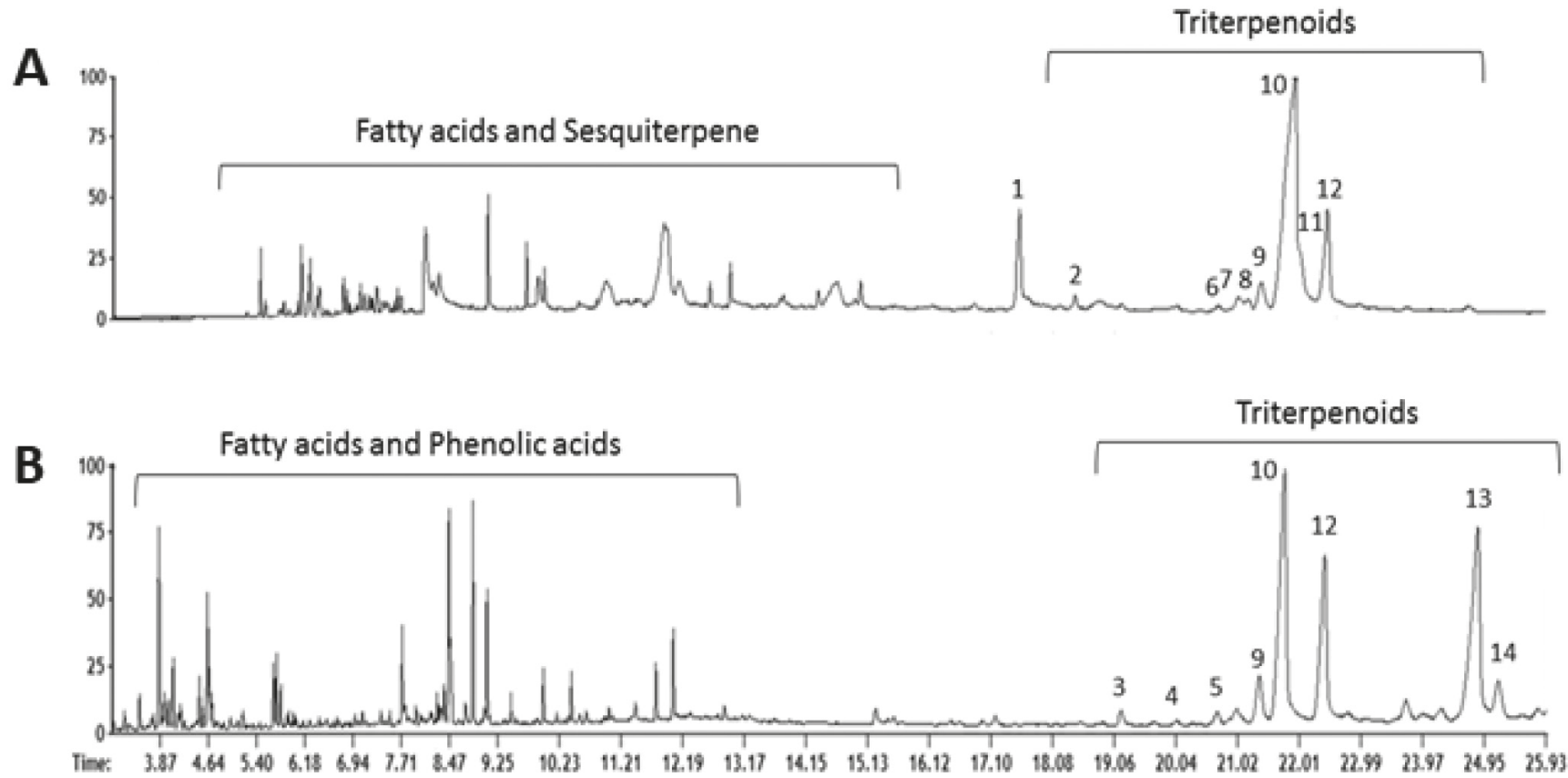

Figure 3. GC-MS chromatograms of silylated samples: (A) hexane; (B) chloroform partitions from the ethanol leaf extract of Eugenia florida 
The MS of peak 5 (20.71 $\mathrm{min}$ ) showed $\mathrm{m} / \mathrm{z} 73$ as the base peak and molecular weight confirmed as $648 \mathrm{Da}$ by the ion $\left[\mathrm{M}-\mathrm{CH}_{3}\right]^{+}$at $\mathrm{m} / \mathrm{z}$ 633. The high similarity of its fragmentation pattern with that observed for peak 6 points toward an ursane-type structure. Losses of 90,118 and $152 \mathrm{Da}$ from the $\mathrm{M}^{+}$suggested the presence of HOTMS and HOOCTMS groups, plus one additional substituent. The observed ion at $\mathrm{m} / \mathrm{z}, 216(23 \%)$ corresponds to a common C*DE fragment $\left[\mathrm{C} * \mathrm{DE}-\mathrm{CH}_{2} \mathrm{OTMS}\right]^{+}$in triterpenoids bearing a $\mathrm{CH}_{2} \mathrm{OTMS}$ group. ${ }^{22}$ Together, these data strongly suggested $\mathbf{5}$ as having the ursane scaffold, although its complete structural characterization is not conclusive.

The compounds corresponding to peaks 7 (21.03 $\mathrm{min})$ and $\mathbf{8}$ (21.19 min) showed molecular ions at $\mathrm{m} / \mathrm{z}, 586$ and 526 , respectively. The fragments at $\mathrm{m} / z, 189$ and 203 and their relative abundances indicated the lupane structure with unsaturated side chains. The MS of 7 present the fragment ion relative to the loss of HOTMS group at $\mathrm{m} / \mathrm{z}$ 496. Such information was confirmed by the presence of the ions at $m / z, 306\left(203+\mathrm{CH}_{2} \mathrm{OTMS}\right)$ and $279(189+\mathrm{HOTMS})$ related to the $\mathrm{C}^{*} \mathrm{DE}$ and $\mathrm{ABC} *$ fragments, respectively. Thus 7 was identified as lup-20(29)-ene-3,28-diol, known as botulin. In the MS of $\mathbf{8}$, the C*DE fragment at $m / z, 320$ indicated the presence of a silylated ester group in C-17. In addition, the ABC* fragment at $m / z, 205$ strongly indicated a ketone in C-3. ${ }^{18}$ Thus, 8 could be identified as 3-oxo-lup20(29)-en-28-oic acid, known as betulonic acid. This is the first report of this compound in Eugenia species.

The MS spectrum of peak 11 (22.87 min) showed a molecular ion at $\mathrm{m} / \mathrm{z}, 512$. The fragment ion at $\mathrm{m} / \mathrm{z} 483$ (loss of $29 \mathrm{Da}$ ) indicated an aldehyde group located in $\mathrm{C}^{*} \mathrm{DE}$ as revealed by loss of $\mathrm{COH}$ from $\mathrm{m} / \mathrm{z} 232$ to generate the fragment at $\mathrm{m} / \mathrm{z} 203$. In addition, the fragment at $m / z, 422$ indicated the loss of a hydroxy group localized in the $\mathrm{ABC}^{*}$ fragment $(\mathrm{m} / \mathrm{z}, 279)$. Thus 11 was identified as betulinaldehyde. This is the first report of betulinaldehyde in Eugenia species.

The MS spectrum of peak 13 (24.86 min) showed $\mathrm{m} / \mathrm{z} .73$ as base peak and $\mathrm{m} / \mathrm{z}, 189$ as the second more abundant ion suggesting that this compound may have a silylated $\Delta^{12}$-lupene-type skeleton. The $\mathrm{M}^{+}$could be deduced as $602 \mathrm{Da}$ from the fragment $\left[\mathrm{M}-\mathrm{CH}_{3}\right]^{+}$ at $\mathrm{m} / \mathrm{z}$. 587. The ions at $\mathrm{m} / \mathrm{z} 512$ and $\mathrm{m} / \mathrm{z} 484$ correspond to the loss of TMSOH and COOTMS groups, respectively, hence confirming the derivatized hydroxyl and carboxyl groups in the molecule. The fragment $C^{*} \mathrm{DE}(\mathrm{m} / \mathrm{z}, 320)$ indicated a COOTMS group in this part of the molecule, whilst the ion at $\mathrm{m} / \mathrm{z}, 559$ originated from the loss of 43 Da possibly corresponding to $\mathrm{C}_{3} \mathrm{H}_{7}$ or $\mathrm{C}_{2} \mathrm{H}_{3} \mathrm{O}$. The low relative intensity of this fragment, and the absent of the ion at $\mathrm{m} / \mathrm{z}, 191$ excluded the possibility of a lupane skeleton with a saturated side chain $\left(\mathrm{C}_{3} \mathrm{H}_{7}\right) .{ }^{20}$ The fragment $\mathrm{ABC}^{*}$ at $m / z, 279$, confirmed a presence of the OTMS group. Therefore, this compound was identified as 3-hydroxy-20-oxo-30-nor-lupan-28-oic acid, known as platanic acid.

The compound corresponding to the peak 14 (25.19 min) showed the base peak at $m / z, 203$ and ions at $m / z, 73,320$ and 189 in decreasing relative abundance. Combined, these data suggested this compound to be a $\Delta^{12}$-ursene-type. ${ }^{13}$ The $\mathrm{M}^{+}$was determined as $688 \mathrm{Da}$ from the fragment $\left[\mathrm{M}-\mathrm{CH}_{3}\right]^{+}$at $\mathrm{m} / z, 673$. The fragments at $\mathrm{m} / z, 598$ and $\mathrm{m} / \mathrm{z}, 570$ correspond to the loss of TMSOH and HCOOTMS, respectively, as expected from the presence of at least one derivatized hydroxyl group and one carboxyl group. The ion at $\mathrm{m} / \mathrm{z} 367$ corresponds to ABC* rings with two silylated hydroxy groups. The ion at $m / z, 320$ was assigned as belonging to the $\mathrm{C} * \mathrm{DE}$ fragment with a silyl ester group located in $\mathrm{C}-17$.

Assuming that one of the hydroxy group is located in C-3 and the fragment at $m / z, 277$ is originated by releasing HOTMS (90 Da) from $\mathrm{m} / \mathrm{z} 367$, an $[1,3]-\mathrm{H}$ shift from $\mathrm{C}(1)$ or $\mathrm{C}(2)$ to the trimethylsilyloxy group in the A ring would be feasible (as exemplified by the totally $O$-silylated 2-hydroxy ursolic acid in Figure 4). Therefore, the second hydroxy group can be located in $\mathrm{C}(1)$ or $\mathrm{C}(2)$, thus characterizing the structure corresponding to peak 14 either as 1-hydroxy- or 2-hydroxyursan-12-en-28-oic acid. Both hydroxy-ursane isomers have been previously found in Myrtaceae spp. ${ }^{24-27}$

UFLC/DAD/ESI-Ion Trap-MS ${ }^{\mathrm{n}}$ was employed to analyze the ethyl acetate and butanol fractions as well as the aqueous residue. This methodology has been used to aid the structural elucidation of polyphenolic contents based on the strategy developed by Abad-García et al. ${ }^{28}$ This approach involved the comparison of the UV spectrum produced by each signal with those from authentic standards.

The samples and authentic standards were submitted to mass fragmentation at different amplitudes, in positive and negative mode, to identify the quasi molecular ions. The experiments in positive mode allowed identifying the protonated aglycone $\left[\mathrm{Y}_{0}\right]^{+}$and its sugar $\left[\mathrm{B}_{1}\right]^{+}$(Figure 5). Loss of 132, 146 or $162 \mathrm{Da}$ indicated the presence of pentose, deoxyhexose (rhamnose) or hexose, respectively. $\mathrm{MS}^{3}$ of protonated aglycone allowed to distinguish among different isomers through analyzing the fragmentation pattern at $0.3 \mathrm{~V}$. Flavonols usually show fragmentation pattern from rDA reaction in the $\mathrm{C}$ ring to accordingly produce characteristic fragments evidencing their substitution pattern. Dihydroflavonols show fragmentation similar in the $\mathrm{C}$ ring with 1,3 and 0,4 retrocyclization cleavages (Figure 5). Phenolic acids were identified through experiments using the negative mode.

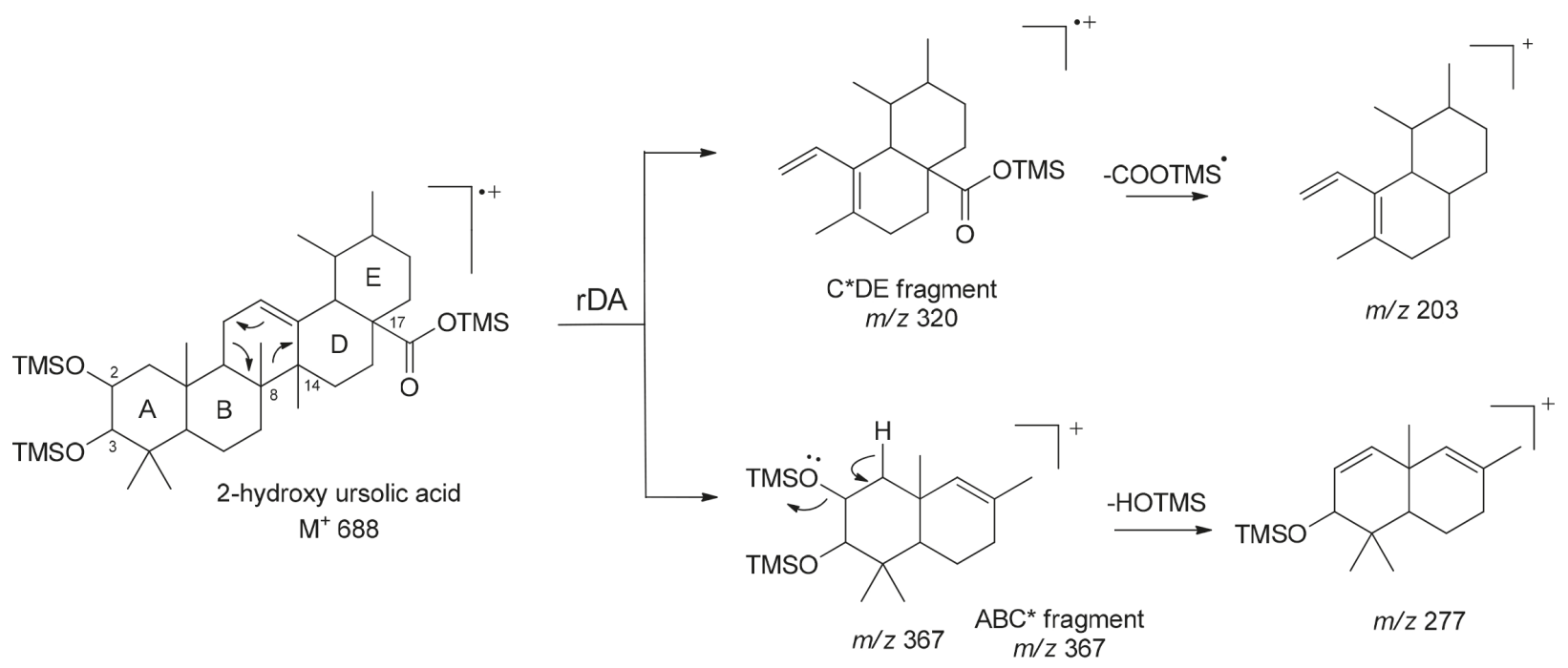

Figure 4. Proposed retro-Diels Alder fragments for 2-hydroxyursan-12-en-28-oic acid by Electron Impact ionization 


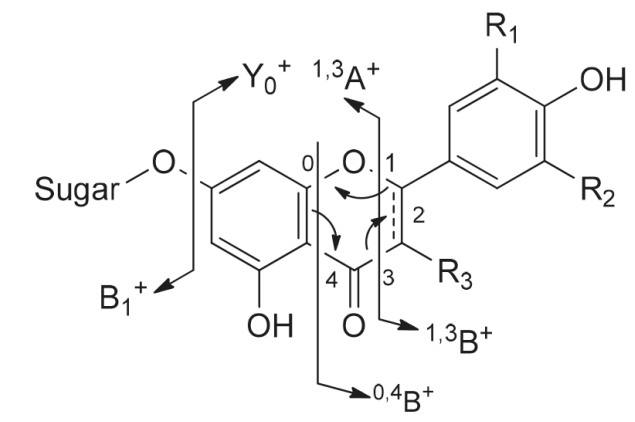

\begin{tabular}{ccccc}
\hline Aglycone & $\mathrm{R}_{1}$ & $\mathrm{R}_{2}$ & $\mathrm{R}_{3}$ & $\Delta^{1,3}$ \\
\hline Myricetin & $\mathrm{OH}$ & $\mathrm{OH}$ & $\mathrm{OH}$ & + \\
Quercetin & $\mathrm{OH}$ & $\mathrm{H}$ & $\mathrm{OH}$ & + \\
Dihydroquercetin & $\mathrm{OH}$ & $\mathrm{H}$ & $\mathrm{OH}$ & - \\
Kaempferol & $\mathrm{H}$ & $\mathrm{H}$ & $\mathrm{OH}$ & + \\
\hline
\end{tabular}

Figure 5. Nomenclature, diagnostic product ions of protonated flavonol- and dihydroflavonol-glycosides ${ }^{28}$ and their aglycones present in Eugenia florida leaves (see Table 4 for complete data)

The polyphenol composition of the ethyl acetate, butanol and aqueous fractions is shown in Tables 3 and 4. Only simple phenolic acids were detected in the aqueous fraction: caffeic acid-hexosedeoxyhexose (peak 15, $1.1 \mathrm{~min}$ ) and ellagic acid (peak 25, $12.1 \mathrm{~min}$ ). The presence of this latter was confirmed by its characteristic UV profile (Figure 6). The ethyl acetate fraction was composed mostly by flavonol- and dihydroflavonol-monoglycosides and contained minor phenolic acids. Myricetin monoglycosides (peaks 26 and 28, 10.7 and 11.6 min, respectively) have been commonly found in Eugenia species. ${ }^{29-31}$ Quercetin monoglycosides (peaks 29, 31 and 32, 11.7, 12.0 and $12.2 \mathrm{~min}$, respectively) and quercetin (peak 35, $14.6 \mathrm{~min}$ ) have been previously identified in the species. ${ }^{3}$ Dihydroquercetin (peak 30, $11.8 \mathrm{~min}$ ) and kaempferol (peak $\mathbf{3 4}, 12.8 \mathrm{~min}$ ) were here identified for the first time in leaves of E. florida. Digalloyl acid (peak 19, $3.0 \mathrm{~min}$ ), chlorogenic acid (peak 22, $8.0 \mathrm{~min}$ ), ellagic acid (peak 25, $12.1 \mathrm{~min}$ ) and quinic galloyl acid (peak 33, $12.5 \mathrm{~min}$ ) were detected in small amounts. The negative mode MS experiments on the butanol fraction led to identification of two monogalloyl-glucose isomers (peaks $\mathbf{1 7}$ and 18, 2.1 and $2.4 \mathrm{~min}$ ), digalloyl acid (peak 19) and chlorogenic acid (peak 22). This fraction also showed lower total quercetin content when compared with the ethyl acetate fraction.

\section{Phenolic compounds quantification and free radical scavenging activity}

The total phenolic content (TPC) and total flavonoid contents (TFC) in the E. florida crude extract and some of its fraction were assessed by the Folin-Ciocalteu and $\mathrm{AlCl}_{3}$ complexation ${ }^{32}$ methods, respectively (Table 5). TPC in the crude extract attained $127 \pm 22 \mathrm{mg} \mathrm{QE} \mathrm{g}^{-1}$, of which the amount of $45.2 \pm 6.9 \mathrm{mg} \mathrm{QE} \mathrm{g}^{-1}$ was due to TFC. The highest TPC were found in the ethyl acetate $\left(400 \pm 29 \mathrm{mg} \mathrm{g}^{-1}\right)$ and butanol $\left(421 \pm 43 \mathrm{mg} \mathrm{g}^{-1}\right)$ fractions, with no significant difference observed between these two fractions, although ethyl acetate extracted the highest amount of flavonoids $\left(93.3 \pm 10.4 \mathrm{mg} \mathrm{QE} \mathrm{g}^{-1}\right)$ by the solvent-partitioning.

The E. florida crude extract and its fractions were effective to scavenge 2,2-diphenyl-1-picrylhydrazyl (DPPH) radical. The corresponding $\mathrm{EC}_{50}$ values (concentration in $\mu \mathrm{g} \mathrm{mL}^{-1}$ required to achieve a 50\% reduction in DPPH radicals) are depicted in Table 5. The crude ethanol extract showed a moderate free radical scavenging activity when compared with the control tert-butylhydroquinone (TBHQ) $\left(\mathrm{EC}_{50} 25.8 \pm 5.7\right.$ and $6.59 \pm 0.03 \mu \mathrm{g} \mathrm{mL} \mathrm{m}^{-1}$, respectively). The highest activities were shown by the ethyl acetate $\left(\mathrm{EC}_{50} 12.2 \pm 0.2 \mu \mathrm{g} \mathrm{mL}^{-1}\right)$ and butanol fractions $\left(\mathrm{EC}_{50} 10.7 \pm 0.2 \mu \mathrm{g} \mathrm{mL}^{-1}\right)$ that presented the highest

Table 3. Phenolic acids detected by UFLC-DAD-MS/MS in negative mode ${ }^{\mathrm{a}}$ in the ethanol leaf extract of Eugenia florida

\begin{tabular}{|c|c|c|c|c|c|c|c|}
\hline Peak & $R \mathrm{t}(\min )$ & Compound & Phenolic class & $\begin{array}{c}\lambda \max ^{\mathrm{b}} \\
(\mathrm{nm})\end{array}$ & {$[\mathrm{M}-\mathrm{H}]^{-}$} & $\mathrm{MS}^{2}$ & $\mathrm{MS}^{3}$ \\
\hline 15 & 1.1 & $\begin{array}{l}\text { Caffeic acid-hex- } \\
\text { ose-deoxyhexose }\end{array}$ & HBZ & 271 & $488(100)$ & $343(100)$ & $\begin{array}{c}263(11), 209(30), 161(46), 143(22), \\
119(11), 113(7.8), 179(100), \\
161(8.3)\end{array}$ \\
\hline 16 & 1.5 & Unidentified & - & 210 & $\begin{array}{l}479(22) \\
317(100)\end{array}$ & $\begin{array}{l}317(100), \\
225(7.4)\end{array}$ & $\begin{array}{c}207(64), 165(49), 164(20), 153(18), \\
149(36), 125(100)\end{array}$ \\
\hline 17 & 2.1 & $\begin{array}{l}\text { Monogalloyl- } \\
\text { glucose }\end{array}$ & HBZ & 270 & $331(100)$ & $\begin{array}{l}331(100), \\
271(39)\end{array}$ & $211(100), 169(5.0), 167(6.0)$ \\
\hline 18 & 2.4 & $\begin{array}{l}\text { Monogalloyl- } \\
\text { glucose }\end{array}$ & HBZ & 270 & $331(100)$ & $\begin{array}{l}331(100), \\
271(29)\end{array}$ & $211(100), 169(5.0), 167(5.0)$ \\
\hline 19 & 3.0 & Digalloyl acid & HBZ & 271 & $\begin{array}{l}339(24), \\
169(100)\end{array}$ & $\begin{array}{l}339(42), \\
169(100)\end{array}$ & $125(100), 124(66)$ \\
\hline 20 & 6.5 & $\begin{array}{l}\text { Quinic acid } p \text { - } \\
\text { coumarate }\end{array}$ & $\mathrm{HCN}$ & 282,333 & $355(100)$ & $163(100)$ & $145(100), 135$ (13), 117 (15) \\
\hline 21 & 7.0 & Unidentified & - & 204,317 & $571(9)$ & $285(100)$ & $153(100)$ \\
\hline 22 & 8.0 & Chlorogenic acid & PHP & $203,284,327$ & $353(100)$ & $\begin{array}{c}353(100), \\
191(40)\end{array}$ & $171(100)$ \\
\hline 23 & 8.1 & Unidentified & - & 202,277 & $\begin{array}{l}785(12), \\
\mathbf{4 8 3}(\mathbf{1 0 0})\end{array}$ & $439(18)$ & 313 (70), 287 (100), 271 (19) \\
\hline 24 & 11.3 & Unidentified & - & 200,275 & $\begin{array}{l}488(27), \\
\mathbf{4 5 3}(\mathbf{1 0 0})\end{array}$ & $451(100)$ & $\begin{array}{c}313(74), 271(97), 223(14), 211(94), \\
193(21), 169(100), 151(22)\end{array}$ \\
\hline 25 & 12.1 & Ellagic acid & HBZ & 253,370 & $301(100)$ & - & - \\
\hline
\end{tabular}

${ }^{\mathrm{a}} \mathrm{m} / z$ (relative abundance). ${ }^{\mathrm{b}} \mathrm{UV}$ spectra recorded online during UFLC-DAD analysis; HBZ = Hydroxybenzoic acid; PHP $=$ Phenylpropanoid; $\mathrm{HCN}=\mathrm{Hydroxy}-$ cinnamic acids. Precursor ion to the following MS experiment is assigned in bold. 
Table 4. Polyphenols detected by UFLC-DAD-MS/MS in positive mode a in the ethanol leaf extract of Eugenia florida

\begin{tabular}{|c|c|c|c|c|c|c|c|c|}
\hline Peak & $R \mathrm{t}(\min )$ & Compound & Phenolic class & $\lambda \max ^{\mathrm{b}}(\mathrm{nm})$ & ${ }^{c}[\mathrm{M}+\mathrm{H}]^{+}$ & ${ }^{\mathrm{c}}\left[\mathrm{Y}_{0}\right]^{+}$ & ${ }^{\mathrm{c}}\left[\mathrm{B}_{1}\right]^{+}$ & Transition ${ }^{\mathrm{d}}[\mathrm{M}+\mathrm{H}]^{+} \rightarrow\left[\mathrm{Y}_{0}\right]^{+}$ \\
\hline 26 & 10.7 & $\begin{array}{l}\text { Myricetin- } O \text { - } \\
\text { rhamnoside }\end{array}$ & FVL & 276,372 & $465(60)$ & $319(100)$ & $147(3)$ & $\begin{array}{c}301(44), 290(19), 283(10), 273(100), \\
263 \text { (17), } 255(18), 245(90), 227(19), \\
217(22), 199(28), 181(31), 169(31), \\
171(12), 153(18), 137(18)\end{array}$ \\
\hline 27 & 11.0 & $\begin{array}{l}\text { Dihydroquercetin- } \\
\text { 3- } O \text {-hexoside }\end{array}$ & DHFVL & 203,281 & $467(5)$ & $305(100)$ & $163(1.3)$ & $\begin{array}{c}287(62), 259(100), 231(9), 195(19), \\
153(70), 149(11)\end{array}$ \\
\hline 28 & 11.6 & $\begin{array}{l}\text { Myricitrin } \\
\text { (myricetin-3-O- } \\
\text { rhamnoside) }\end{array}$ & FVL & 262,350 & $465(37)$ & $319(100)$ & $147(<1)$ & $\begin{array}{c}301(31), 290(13), 283(9), 273(100), \\
263(14), 255(18), 245(43), 227(7), \\
217(13), 195(6), 179(8), 177(8), \\
165(43), 153(55), 137(5), 127(5)\end{array}$ \\
\hline 29 & 11.7 & $\begin{array}{l}\text { Quercetin-3-O- } \\
\text { hexoside }\end{array}$ & FVL & 255,353 & $465(100)$ & $303(66)$ & $163(1.0)$ & $\begin{array}{c}285(37), 274(14), 257(100), 247(16), \\
239(3), 229(100), 201(18), 173(5), \\
165(54), 137(27), 111(5)\end{array}$ \\
\hline 30 & 11.8 & $\begin{array}{l}\text { Taxifolin } \\
\text { (Dihydroquercetin- } \\
\text { 3-O-rhamnoside) }\end{array}$ & DHFVL & 288 & $451(33)$ & $305(100)$ & $147(<1)$ & $\begin{array}{c}287(67), 259(100), 231(16), 195(17), \\
153(76), 149(21)\end{array}$ \\
\hline 31 & 12.0 & $\begin{array}{l}\text { Quercetin-3-O- } \\
\text { pentoside }\end{array}$ & FVL & 256,354 & $435(100)$ & $303(70)$ & $133(1.3)$ & $\begin{array}{c}285(47), 274(15), 257(90) 247(23), \\
229(100), 201(23), 165(51), 153(15), \\
149(13), 137(21)\end{array}$ \\
\hline 32 & 12.2 & $\begin{array}{l}\text { Quercitrin } \\
\text { (quercetin-3-O- } \\
\text { rhamnoside) }\end{array}$ & FVL & 255,349 & $449(38)$ & $303(100)$ & $148(<1)$ & $\begin{array}{c}285(51), 274(13), 257(89), 247(19), \\
229(100), 213(8), 201(19), 165(71), \\
153(21), 137(25), 121(7)\end{array}$ \\
\hline 33 & 12.5 & Quinic galloyl acid & $\mathrm{HBZ}$ & 279 & $343(22)$ & $191(100)$ & $153(<1)$ & $\begin{array}{c}163(100), 145(24), 135(46), 121(4), \\
117(3,4), 107(13,9)\end{array}$ \\
\hline 34 & 12.8 & $\begin{array}{l}\text { Afzelin } \\
\text { (kaempferol-3-O- } \\
\text { rhamnoside) }\end{array}$ & FVL & 265,347 & $433(63)$ & $287(100)$ & $147(<1)$ & $\begin{array}{c}269(15), 257(51), 241(100), 231(29), \\
213(95), 203(20), 197(21), 165(83), \\
157(23), 153(60), 121(18), 111(17)\end{array}$ \\
\hline 35 & 14.6 & Quercetin & FVL & 255,372 & - & $303(100)$ & - & - \\
\hline 36 & 15.9 & Kaempferol & FVL & 278,371 & - & $287(100)$ & - & - \\
\hline
\end{tabular}

${ }^{\mathrm{a}} \mathrm{m} / \mathrm{z}$ (relative abundance). ${ }^{\mathrm{b}} \mathrm{UV}$ spectra recorded online during UFLC-DAD analysis; ${ }^{\mathrm{c}}$ Fragments obtained in the MS ${ }^{1}$ experiment; ${ }^{\mathrm{d}}$ Fragments obtained in the $\mathrm{MS}^{3}$ experiment of transition $[\mathrm{M}+\mathrm{H}]^{+} \rightarrow\left[\mathrm{Y}_{0}\right]^{+}$. FVL $=$Flavonol; DHFVL $=$Dihydroflavonol; HBZ $=$Benzoic acid.

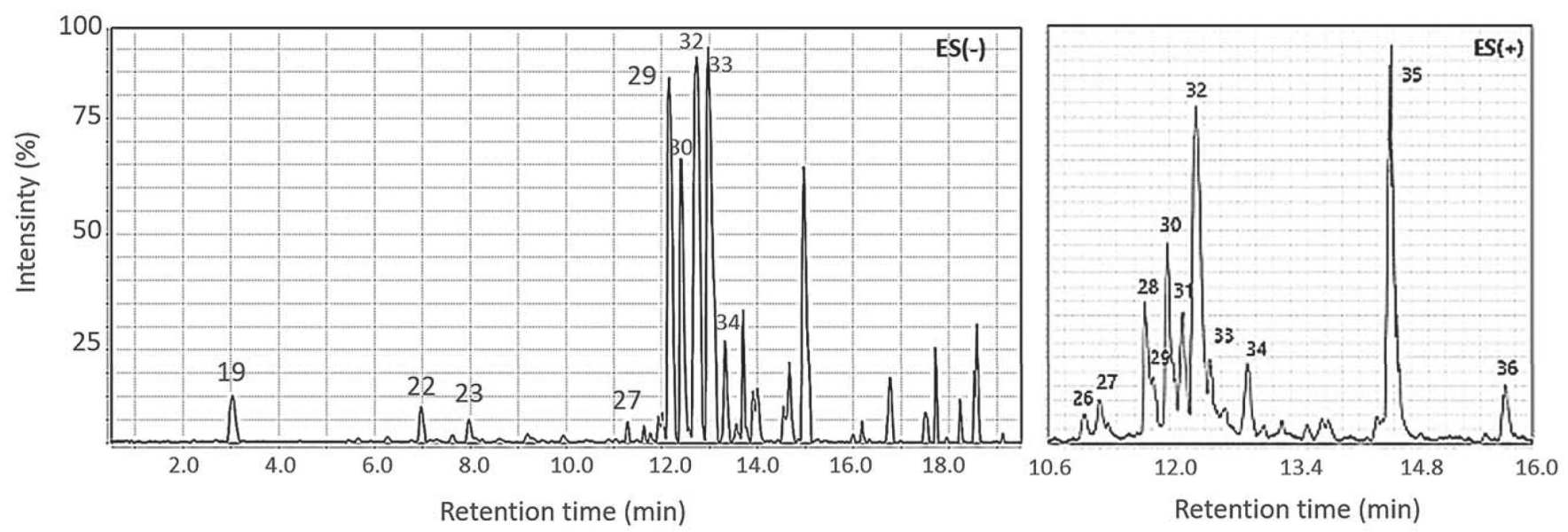

Figure 6. Total ion chromatogram (TIC) of the ethyl acetate fraction from the ethanol leaf extract of Eugenia florida in negative mode [ES(-)] and expansion of TIC in positive mode [ES(+)]

TPC as well. In fact, these values can be interpreted as of high activity considering achieving only twice the value of the positive control. Thus, the solvent partition was efficient to enrich the fractions in free radical scavengers as well as in phenolic compounds, in the following order: butanol $>$ ethyl acetate $>$ water $\approx$ crude ethanol extract $>>$ chloroform $>>$ hexane. Quenching of DPPH radical is a rapid and simple assay to assess the potential of substances to scavenge free radicals and so to play an important role as antioxidants. Polyphenols can act as free radical scavengers by quenching $\mathrm{DPPH}^{33}$ as well highly reactive oxygen species as hydroxyl radical and superoxide anion radical, ${ }^{34}$ that cause to organic tissues, under continuous exposition to those, the risk of aging, degenerative diseases and cancer initiation. ${ }^{35}$

The relationship between phenolic compounds and antioxidant activity has been well-described for different parts of Eugenia species 
Table 5. Total Phenolic Content (TPC), Total Flavonoid Content (TFC) and free radical scavenging activity $\left(\mathrm{EC}_{50}\right)$ of crude ethanol extract of Eugenia florida and its fractions ${ }^{\mathrm{a}}$

\begin{tabular}{lcccc}
\hline $\begin{array}{l}\text { Extract and } \\
\text { fraction }\end{array}$ & $\begin{array}{c}\mathrm{TPC} \\
\left(\mathrm{mg} \mathrm{QE} \mathrm{g}^{-1}\right)\end{array}$ & $\begin{array}{c}\mathrm{TFC} \\
\left(\mathrm{mg} \mathrm{QE} \mathrm{g}^{-1}\right)\end{array}$ & $\begin{array}{c}\mathrm{EC}_{50} \\
\left(\mu \mathrm{g} \mathrm{mL}^{-1}\right)\end{array}$ & $\begin{array}{c}\text { Fraction } \\
\text { yield }(\%)\end{array}$ \\
\hline Ethanol extract & $127 \pm 22^{\mathrm{a}}$ & $45.2 \pm 6.9$ & $25.8 \pm 5.7^{\mathrm{a}}$ & - \\
Hexane & - & - & $859 \pm 1.88^{\mathrm{b}}$ & 14.4 \\
Chloroform & $36.9 \pm 0.0^{\mathrm{b}}$ & - & $243 \pm 3.20^{\mathrm{c}}$ & 25.7 \\
Ethyl Acetate & $400 \pm 29^{\mathrm{c}}$ & $93.3 \pm 10.4$ & $12.2 \pm 0.20^{\mathrm{d}}$ & 14.6 \\
Butanol & $421 \pm 43^{\mathrm{c}}$ & $38.6 \pm 0.0$ & $10.7 \pm 0.2^{\mathrm{d}}$ & 12.9 \\
Water & $210 \pm 24^{\mathrm{d}}$ & $\mathrm{nd}$ & $32.0 \pm 0.6^{\mathrm{a}}$ & 13.5 \\
TBHQ & - & - & $6.59 \pm 0.03^{\mathrm{d}}$ & -
\end{tabular}

${ }^{a}$ Results are shown as mean \pm standard deviation $(\mathrm{SD}) ; \mathrm{QE}=$ quercetin equivalent; ANOVA analysis for identification of significant statistical differences followed Tukey's Multiple Comparison Test; Equal indexes (a, b, c, d) express results with no statistically significant difference $(p>0.05)$; nd $=$ not detected.

as the leaves, ${ }^{36}$ fruits and seeds ${ }^{37}$ Spread use in the folk medicine ${ }^{38}$ coupled with the fact of producing tasty and edible fruits ${ }^{39}$ have fostering recent investigations on the potential of such species as natural antioxidants. ${ }^{40}$ In this sense, extracts from Eugenia species would be suitable to compose new functional foods with anticancer potential, or act in multicomponent therapies, on the basis of their potential to prevent the carcinogenicity induced by high levels of free radicals. ${ }^{35}$

\section{Antiproliferative assays}

In the present study, the in vitro anti-proliferative effects of the ethanol leaf extract and fractions of E. florida were evaluated on tumor cell lines by the MTT method. The crude ethanol extract was able to inhibit the growth of K562 (human myeloid leukemia) in a dose-dependent manner $(p<0.05)$ and at strong logarithm correlation (Pearson- $\mathrm{r}=0.92$ ), hereby emphasizing thereof the strong effects at $15 \mu \mathrm{g} \mathrm{mL}^{-1}(50 \%)$ and $150 \mu \mathrm{g} \mathrm{mL} \mathrm{m}^{-1}(80 \%)$ (Figure 7). The $\mathrm{IC}_{50}$ was calculated as $12 \mu \mathrm{g} \mathrm{mL} \mathrm{m}^{-1}$, which is close to the value found for Eugenia punicifolia leaf hydroethanolic extract acting on the same cell line $\left(\mathrm{IC}_{50} 12.9 \pm 7.2 \mu \mathrm{g} \mathrm{mL}^{-1}\right){ }^{41}$

Few studies are available on the anti-proliferative potential of extracts from Eugenia species. When screened against the growth of eight tumor cell lines, the hexane-methanol leaf extract of $E$. florida produced the best inhibition with OVCAR-3 (ovarian cancer, $\mathrm{IC}_{50}$ $1.6 \mu \mathrm{g} \mathrm{mL}-1) .{ }^{42}$ The 7:3 acetone-water leaf extracts of Eugenia jambolana (syn. Syzygium cumini) and E. jambos were able to inhibit the growth (> 86\%) of human promyelocytic leukemia cells (HL-60), at $100 \mu \mathrm{g} \mathrm{mL}{ }^{-1}{ }^{43}$

The inhibition of K562 cell line was assayed with the solventpartitioned fractions derived from the active ethanol extract of E. florida at the fixed dose of $15 \mu \mathrm{g} \mathrm{mL}-1$ (Figure 8). The highest inhibitory levels (above 25\% inhibition) were achieved by the hexane and ethyl acetate fractions, with no statistically significant differences between them $(p>0.05)$. Given the equivalent yields (14\%, Table 5), both might have equally contributed for the crude extract activity. The chloroform, butanol and aqueous fractions showed below $12 \%$ inhibition and no significant differences were observed.

Taking together, the cytotoxic potential observed for the crude extract and derived fractions from it suggested that inhibitory activity would be associated to more than one class of secondary metabolites as characterized in this study, since the highest activities were found in fractions originated from very distinct solvent partition.

It is well described that triterpene acids can exert cytotoxic activity,

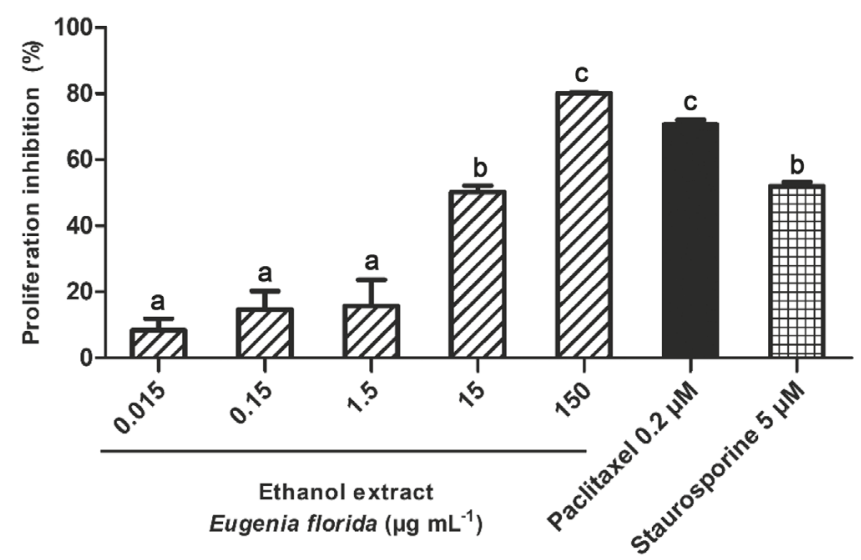

Figure 7. Effect of different concentrations of the ethanol leaf extract of Eugenia florida on the inhibition of human leukemia cell proliferation (K562). Results are shown as mean \pm standard deviation $(S D)$. Equal indexes $(a, b, c)$ express results with no statistically significant difference $(p>0.05)$

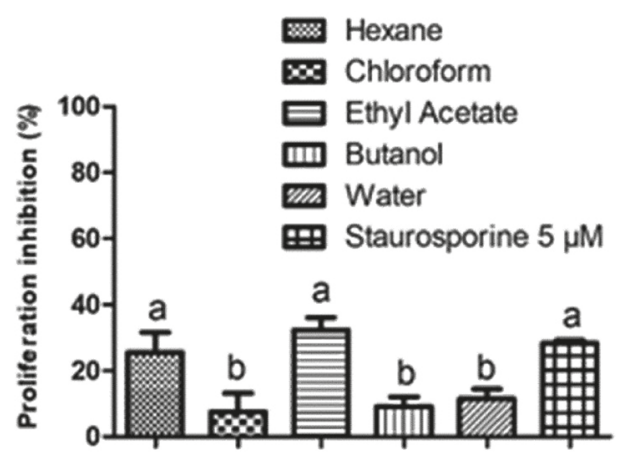

Figure 8. Effect on the proliferation of human leukemia cell (K562) of one dose $\left(15 \mu \mathrm{g} \mathrm{mL} L^{-1}\right)$ of the fractions obtained from sequential partition of the ethanol leaf extract of Eugenia florida. Results are shown as mean \pm standard deviation $(S D)$. Equal indexes $(a, b)$ express results with no statistically significant difference $(p>0.05)$

as exemplified by oleanolic acid, ursolic acid and betulinic acid. ${ }^{44,45}$ In fact, betulinic and ursolic acids were able to inhibit the growth and induced apoptosis of K562 cell line in a dose dependent manner. ${ }^{46}$ Hence, even though the hexane and chloroform partitions of the $E$. florida ethanol extract contain triterpene acids (as seen above), the stronger anti-proliferative effect on K562 cell line by the former can be associated to its high content of betulinic acid. It is worthy to notice that the hexane fraction also contains a representative amount of fatty acids and other low-polar compounds, as shown in the GC-chromatogram (Figure 3A). Association between these compounds and any specific cytotoxicity is not reported in the literature; however, they are capable to aid the triterpenes solubility in aqueous media, thus enhancing their ability to reach the targeted cells. ${ }^{47}$

In the same way, the increased inhibition capacity observed for the ethyl acetate fraction compared with the butanol and aqueous fractions can be related to the largest amount of TFC in the former (Table 5). The aqueous and butanol fractions inhibited the proliferation at similar levels. When tested in vitro against the proliferation of SK-Mel-28 cells (melanoma), all the fractions from E. florida ethanol extract resulted no significant activity $(p>0.05)$ (data not shown).

\section{CONCLUSIONS}

This study contributed to increase the knowledge on the leaf chemical composition of Eugenia florida by complementing previously 
reported data, ${ }^{3,5-7}$ as well as assessed its antioxidant and cytotoxic potential. It was possible to detect fourteen triterpenoids through a detailed analysis of their trimethylsylil derivative mass fragmention pathways on GC-MS and eighteen polyphenolic compounds identified with basis on their mass fragmentation patterns by UFLC/DAD/ ESI-Ion Trap-MS ${ }^{\mathrm{n}}$. and comparison, in both cases, with standards and/or data reported in the literature. Fatty acids (C14, C16, C18, C18:1), several sesquiterpenes and phenolic acids (2-hydroxybenzoic acid, protocatechoic acid, $p$-coumaric acid, gallic acid and ferulic acid) were also characterized in the fractions (Table 2S). Betulinaldehyde, dihydroquercetin and kaempferol were here identified by the first time in leaves of E. florida. The free radical scavenging test showed that antioxidant compounds concentrated in the ethyl acetate and butanol which are rich in polyphenols. Antiproliferative potential of $E$. florida was here first reported. All of its solvent-partitioned fractions showed activity against K562 cell with emphasis in the polyphenolic- and triterpenic-rich fractions, albeit no activity was observed against SK-Mel-28 cell line. An anti-proliferative effect against chronic myeloid leukemic cells was identified for E. florida leaves.

\section{SUPPLEMENTARY MATERIAL}

Tables $1 \mathrm{~S}$ and $2 \mathrm{~S}$ are available for free download at http:// quimicanova.sbq.org.br in pdf format.

\section{ACKNOWLEDGEMENTS}

The authors express their gratitude to Dr. Marcelo M. Pereira, MSc. Matheus Oliveira, Dr. Denise M. G. Freire (IQ-UFRJ) and Mr. Fabio Diniz from the Instituto de Química of the Universidade Federal do Rio de Janeiro for supporting the research work. The authors grateful the Plataforma de Métodos Analíticos of the Far-Manguinhos (Fiocruz, Brazil) for the UFLC analyses.

\section{REFERENCES}

1. Heywood, V. H.; Brummitt, R. K.; Culham, A.; Seberg, O.; Flowering Plant Families of the World, Firepfly Books (US) Inc: Buffalo, New York, 2007.

2. Lima, A. M. B.; Siani, A. C.; Nakamura, M. J.; D’Avila, L. A.; Pharmacogn. Mag. 2015, 11, 470.

3. Bastos, R. G.; Rosa, C. P.; Oliver, J. C.; Silva, N. C.; Dias, A. L. T.; Rocha, C. Q.; Vilegas, W.; Silva, G. A.; Silva, M. A.; Int. J. Pharm. Pharm. Sci. 2016, 8, 110.

4. Torres, A. F.; Lasmar, O.; Carvalho, G. A.; Santa-Cecília, L. V. C.; Zanetti, R.; Oliveira, D.; Coffee Sci., Lavras 2013, 8, 371.

5. Apel, M. A.; Sobral, M.; Schapoval, E. E. S.; Henriques, A. T.; Menut, C.; Bessiere, J.-M.; J. Essent. Oil Res. 2004, 16, 321.

6. Junges, M. J.; Fernandes, J. B.; Vieira, P. C.; Silva, M. F. G. F.; Rodrigues Filho, E.; J. Braz. Chem. Soc. 1999, 10, 317.

7. Barreto, A. S.; Feliciano, G. D.; Nascimento, C. C. H. C.; Luna, C. S.; Lessa, B. M.; Silveira, C. F.; Barbosa, L. S.; Amaral, A. C. F.; Siani, A. C.; Acad. J. Biotechnol. 2013, 1, 21

8. Farasat, M.; Khavari-Nejad, R. A.; Nabavi, S. M.; Namjooyan, F.; Iran J. Pharm. Res. 2014, 13, 163.

9. Fernandes, A. S.; Mazzei, J. L.; Oliveira, C. G.; Evangelista, H.; Marques, M. R.; Ferraz, E. R.; Felzenszwalb, I.; Toxicology 2017, 376, 126.

10. Lima, A. M. B.; d'Avila, L. A.; Siani, A. C.; Chromatographia 2014, 77, 629.

11. Budzikiewicz, H.; Wilson, J. M.; Djerassi, C.; J. Am. Chem. Soc. 1963, $85,3688$.
12. Caligiani, A.; Malavasi, G.; Palla, G.; Marseglia, A.; Tognolini, M.; Bruni, R.; Food Chem. 2013, 136, 735.

13. Mathe, C.; Culioli, G.; Archier, P.; Vieillescazes, C.; J. Chromatogr. A 2004, 1023, 277.

14. Razborsek, M. I.; Voncina, D. B.; Dolecek, V.; Voncina, E.; Chromatographia 2008, 67, 433.

15. Johnson, S. R.; Lange, B. M.; Front. Bioeng. Biotechnol. 2015, 3, 1.

16. Li, Y.; Xu, J.; Yuan, C.; Ma, H.; Liu, T.; Liu, F.; Seeram, N. P.; Mu, Y.; Huang, X.; Li, L.; J. Funct. Foods 2017, $28,1$.

17. Burnouf-Radosevich, M.; Delfel, N. E.; England, R.; Phytochemistry 1985, 24, 2063.

18. Assimopoulou, A. N.; Papageorgiou, V. P.; Biomed. Chromatogr. 2005, 19, 285.

19. Moldoveanu, S. C.; Scott, W. A.; J. Sep. Sci. 2016, 39, 324.

20. Ogunkoya, L.; Phytochemistry 1981, 20, 121.

21. Martín, R.; Ibeas, E.; Carvalho-Tavares, J.; Hernández, M.; RuizGutierrez, V.; Nieto, M. L.; PLoS One 2009, 4, e5975.

22. Wretensjö, I.; Karlberg, B.; J. Am. Oil Chem. Soc. 2002, 79, 1069.

23. Siani, A. C.; Nakamura, M. J.; Tappin, M.; Monteiro, S. S.; Guimarães, A. C.; Ramos, M. F.; Phytochem. Anal. 2012, 23, 529.

24. Gohar, A. A.; Maatooq, G. T.; Gadara, S. R.; Aboelmaaty, W. S.; Nat. Prod. Res. 2013, 27, 1179.

25. Shu, J.; Yu, G.; Wang, Z.; Zhongguo Zhongya Zazhi 2009, 34, 3047.

26. Rangasamy, O.; Mahomoodally, F. M.; Gurib-Fakim, A.; QuetinLeclercq, J.; South Afr. J. Bot. 2014, 93, 198

27. Yakasi, Y.; Phytochemistry 1977, 16, 138.

28. Abad-Garcia, B.; Berrueta, L. A.; Garmon-Lobato, S.; Gallo, B.; Vicente, F.; J. Chromatogr. A 2009, 1216, 5398.

29. Mahmoud, I. I.; Marzouk, M. S. A.; Moharram, F. A.; El-Gindi, M. R.; Hassan, A. M. K.; Phytochemistry 2001, 58, 1239.

30. Slowing, K.; Söllhuber, M.; Carretero, E.; Villar, A.; Phytochemistry 1994, 37, 255.

31. Siebert, D. A.; Bastos, J.; Spudeit, D. A.; Micke, G. A.; Alberton, M. D.; Rev. Bras. Farmacogn. 2017, 27, 459.

32. Pękal, A.; Pyrzynska, K.; Food Anal. Methods 2014, 7, 1776.

33. Liu, Z.-Q.; Chem. Rev. 2010, 110, 5675.

34. Agatia, G.; Azzarellob, E.; Pollastri, S.; Tattini, M.; Plant Sci. 2012, 196, 67.

35. Valko, M.; Izakovic, M.; Mazur, M.; Rhodes, C. J.; Telser, J.; Mol. Cell. Biochem. 2004, 266, 37.

36. Carvalho Junior, A. R.; Gomes, G. A.; O., F. R.; Carvalho, M. G.; Quim. Nova 2014, 37, 477.

37. Teixeira, L. D.; Bertoldi, F. C.; Lajolo, F. M.; Hassimotto, N. M.; J. Agr. Food Chem. 2015, 63, 5417.

38. Takao, L. K.; Imatomi, M.; Gualtieri, S. C.; Braz. J. Biol. 2015, 75, 948.

39. Reynertson, K. A.; Yang, H.; Jiang, B.; Basile, M. J.; Kennelly, E. J.; Food Chem. 2008, 109, 883.

40. Cai, Y.; Luo, Q.; Sun, M.; Corke, H.; Life Sci. 2004, 74, 2157.

41. Costa, M. F.; Jesus, T. I.; Lopes, B. R. P.; Angolini, C. F. F.; Montagnolli, A.; Gomes, L. P.; Pereira, G. S.; Ruiz, A. L. T. G.; Carvalho, J. E.; Eberlin, M. N.; Santos, C.; Toledo, K. A.; BMC Complementary Altern. Med. 2016, 16, 403.

42. Nóbrega, A. B.; MSc Dissertation, Universidade Federal Fluminense, Brasil, 2011.

43. Yang, L.-L.; Lee, C.-Y.; Yen, K.-Y.; Cancer Lett. 2003, 190, 165.

44. Zhang, W.; Men, X.; Lei, P.; J. Can. Res. Ther. 2014, 10, 14.

45. Ali-Seyed, M.; Jantan, I.; Vijayaraghavan, K.; Bukhari, S. N.; Chem. Biol. Drug Des. 2016, 87, 517.

46. Fernandes, J.; Castilho, R. O.; da Costa, M. R.; Wagner-Souza, K.; Coelho Kaplan, M. A.; Gattass, C. R.; Cancer Lett. 2003, 190, 165.

47. Jäger, S.; Winkler, K.; Pfüller, U.; Scheffler, A.; Planta Med. 2007, 73, 157. 